Vol. 6, No. 2, 2019

https://doi.org/10.23939/eem2019.02.022

UDC 005.9

JEL Classification Code L31

A. Frączkiewicz-Wronka,

University of Economics in Katowice, Poland, Doctor, Professor,

E-mail: aldona.fraczkiewicz-wronka@ue.katowice.pl

ORCID: 0000-0002-7077-1068

M. Wronka-Pośpiech,

University of Economics in Katowice, Poland, PhD, Associate Professor

E-mail: martyna.wronka-pospiech@ue.katowice.pl

ORCID: 0000-0001-9240-6670

R. Porc,

Social Welfare Home, Zawiercie, Poland, MSc, Director

\title{
SOCIAL ENTERPRISES AS PLACE OF WORK FOR PEOPLE WITH DISABILITIES - EVIDENCE FROM POLAND
}

\begin{abstract}
Concern about people with disabilities is now becoming one of the areas of interest within the European Union, which is seeking a costeffective and socially acceptable solutions aimed at supporting a worthy life of this group of society. Specific areas of action aimed at improving conditions for social inclusion, well-being and the full exercise of the rights of people with disabilities are set out in the "European Disability Strategy 2010-2020: A renewed commitment to a Barrier-Free Europe" (European Disability Strategy 2010-2020: COM (2010) 636). Employment is one of those areas. In order to cope with the professional activation of people with disabilities the pattern of change should start from the immediate environment and living space of disabled. Increasing the number of employment opportunities (e.g. in the form of homework), create and ease the options for self-employment (e.g. social cooperatives). Therefore, the aim of this article is to look at how social enterprises act as labour market entities and what are results of their activity in Poland. We try to prove that social enterprises, i.e. social cooperatives are important entity for the activation of people with disabilities in the labour market by providing the analysis of the activities of two subjects.
\end{abstract}

Key words: public management, social enterprise, European Disability Strategy, professional activation, disability

\section{Introduction}

A fundamental problem faced by the developed countries is to find such practices for public funds management that will allow for the effective achievement of social goals defined in the process of political choices made by citizens. It is crucial that the final outcome - the service provided - should be economically sound, qualitatively satisfying and compliant with the rules of social fairness.

The European Disability Strategy 2010-2020 is the EU's agenda for growth and jobs for the current decade. It is aimed at maximizing the involvement of all actors, especially third sector organizations, within local area in implementing social tasks. The idea of non-state actors is not to replace local authorities; it is rather enrichment in meeting growing social requirements. Third sector organizations can be a solution to the growing problem of municipalities. Local authorities, using law and policies, should encourage the formation and functioning of social cooperatives. Moreover, public services are now regarded as a key factor in boosting the competitiveness of the economy and ensuring social and territorial cohesion. That is why 


\section{Social enterprises as place of work for people with disabilities - evidence from Poland}

proper actions should be undertaken, to empower local authorities, scout for resources, train social workers, inform and educate the employers to change their attitudes, modify the infrastructure to facilitate the access for handicapped and the most important, to stimulate the growth of third sector.

Actions undertaken to create jobs and conditions for the employment of disadvantaged people, including the disabled, are of particular importance for achieving social goals (Zrałek \& Borski, 2018). In Poland, in 2018 the employment rate for people aged 20-64 was $72.8 \%$, which places us slightly below the average for the entire European Union (73.5\%). It is worth remembering that in the Scandinavian countries the total employment rate exceeded $80 \%$, however in countries with a similar socio-economic situation to Poland it was significantly higher: Latvia $77.7 \%$, Lithuania $78.1 \%$, and the Czech Republic $80.1 \%$. For women this indicator looks worse $-65.5 \%$ in Poland compared to $67.5 \%$ in the EU. According to BAEL data, among the inactive people, apart from learners and retirees, the most numerous groups were inactive because of: (1) family and homerelated responsibilities (1.8 million); (2) illness and disability (approx. 1.5 million); and (3) discouragement stemming from the ineffective job search (approx. 237 thousand). Particular attention should be paid to people with disabilities whose professional activity rate was $18.3 \%$ in 2018 , which is half of the EU average. It is estimated that about 1.2 million - 1.4 million people with disabilities are inactive (BAEL 2018). For this group of society, employment in social economy entities, including social enterprises, can be a good way of reintegration into the labour market. The development of the social policy concept, in particular the attempts to implement practical solutions characteristic of active social policies, influenced the emergence of new provision methods for social services. One of such methods, which have recently gained in popularity, is the creation and growth of social economy entities. Such entities are a natural organizational response to the need for such pro-social solutions that, as their prime concern, pursue social goals while ensuring economic return on the invested public funds. By definition, the social economy is a system of enterprises and organizations, with respective legal regulations, which aim to support those at risk of social exclusion. The primary role of the social economy is to prevent social exclusion. The groups that are particularly threatened with social exclusion are disabled people.

The need for social economy and social enterprises arises from the fact, that traditional political and economic solutions are no longer good enough to guarantee a minimal quality of life to a rising number of people. Therefore, social economy appears as an answer to the increasing disproportions between the rich and the poor and a response to the exclusion of large social groups from mainstream social life, such as people with disabilities. While social economy has been and is quite active in the context of activating the unemployed, it has not been used to that extent as an employment opportunity for inactive people such as people with disabilities. Therefore, the aim of this article is to look at how social enterprises act as labour market entities and what are results of their activity in Poland.

\section{European disability strategy 2010-2020}

The European Disability Strategy 2010-2020 adopted by the European Commission in November 2010 , represents a fundamental policy instrument for persons with disabilities and their organisations to be used in order to make a barrier-free Europe. The Strategy identifies eight main areas for action and focuses on eliminating barriers in those domains: Accessibility (a prerequisite for participation of people with disabilities in social and economic life), Participation (subjected to accessibility, as the existence of any barriers hinders the opportunity to participate in local society), Equality (the essence is to take steps to eliminate discrimination on any grounds, especially disability, and guarantee effective protection from any discriminations), Employment (occupational training, guidance), Education and Training (low level of education, which adversely situates people with disabilities in the labour market, to transform, upgrade), Social Protection (the area of social protection associated with the right to retirement benefits and pensions, appropriate living conditions, clothing and housing adapted to the limitations resulting from the disability and financial capacity), Health (striving to ensure the access to health treatment and care, early diagnosis, rehabilitation and therapeutic education), and External Actions (increase the awareness and 


\section{A. Frączkiewicz-Wronka, M. Wronka-Pośpiech, R. Porc}

knowledge of people with disabilities, about their rights and ways to enforce them, raising the awareness of the whole society including employees of government institutions and organizations). Each area has assigned and identified key actions, selected on the basis of their potential contribution to Strategy and EU objectives.

According to the European Disability Strategy 2010-2020, employment of disabled people should be supported but also monitored. Commitment of local authorities should rise, be duty-bounded, true and long lasting.

Table 1 presents a brief summary of major European Disability Strategy assumptions and directions. Goals listed are meant to be achievable and completing them may bring independency to those, who need it most, especially for individuals with disabilities.

\section{Summary of major european disability strategy}

Table 1

\begin{tabular}{|c|c|}
\hline Field & Employment \\
\hline $\begin{array}{l}\text { The overriding } \\
\text { objective - EU level }\end{array}$ & $\begin{array}{l}\text { Enabling much larger number of people with disabilities to earn for a living on the open } \\
\text { labour market. }\end{array}$ \\
\hline $\begin{array}{l}\text { The actions envisaged } \\
\text { in the strategy }\end{array}$ & $\begin{array}{l}\text { To support national efforts and: analyse the situation of people with disabilities on the } \\
\text { labour market; combat negative, discouraging attitudes and traps associated with } \\
\text { demanding process of getting help and other benefits; assistance in people integration on } \\
\text { the labour market through the use of the European Social Funds; continuous } \\
\text { development of active labour market policies; increase the number of jobs offered; } \\
\text { support structures and trainings in the workplace; }\end{array}$ \\
\hline $\begin{array}{l}\text { Examples of activities } \\
\text { at the municipality level }\end{array}$ & $\begin{array}{l}\text { Living space and immediate environment } \\
\text { - } \quad \text { increase the number of employment opportunities in the form of homework } \\
\text { - improvilocation and tele-homeworking) } \\
\text { - development of database with designated job offers (telework offers only) } \\
\text { Wider environment of residence } \\
\text { - development of home-to-work roadmap for disabled to make commuting safe and } \\
\text { - possible } \\
\text { - inclusion of social economy in the process of professional activation and integration } \\
\text { - of those with limited or reduced efficiency } \\
\text { - increase the number of professional workshops, vocational development and training } \\
\text { - centres } \\
\text { - 'trampain the trainer' sessions for fully engaged in professional activation of disabled, } \\
\text { on job training for employees and employers (HR specialists, advisers, tutors) }\end{array}$ \\
\hline
\end{tabular}

Source: Mokrzycka, A., (2012). European Strategies Towards Rights of Disabled Persons - the meaning of The Disability action plan and European disability Strategy 2010-2020. Polityka Spoteczna, special issue, Warszawa, 61-70

The number of people claiming incapacity benefits increased rapidly in recent years. That is why the main objective of the strategy is to enable much larger number of people with disabilities to earn for a living on the open labour market. Government support programs have important implications for employment outcomes through the incentives that they create for workforce participation. As it was highlighted in the Strategy, municipalities can try to support people with disabilities inter alia through inclusion of social economy in the process of their professional activation and integration. That can be achieved by making it easier to establish social enterprises. 


\section{Characteristics of social enterprises}

Considerable discrepancies exist as to the meaning of a social enterprise. First of all, it combines the characteristics of a non-governmental organization and a market entity, creating new jobs and setting additional goals of sustaining these jobs and providing services to local communities (Leś, 2004). Based on the proposal included in the UK government document, social enterprise can be defined as an institution that runs business activity, sets primarily social goals, reinvests the earned surplus for those purposes in the business or in the community, rather than being driven by the need to maximize profits for shareholders and owners (Dacin, Dacin \& Matear, 2002). R. Dart argues that in order to fully understand the potential locked in social entrepreneurship, it is necessary to accurately define the concept of "a social enterprise" (Dart, 2004). Generally, it is regarded as a basic institution of the social economy, a manifestation of new entrepreneurship, which pursues social obligations and is shaped by practices of the third sector. They can adopt one of many available legal forms, but they share the commitment to finding solutions, based on commercial experiences, which will allow them to pursue social goals and reinvest profits from the operations with the benefit for the community (Haugh, 2006). J. Thompson and B. Doherty define them as organisations that apply business solutions to address social problems (Thompson \& Doherty, 2006), while J. Hausner claims that they are part of the market economy that places their objectives and mission outside the market (Hausner, Laurisz \& Mazur, 2007).

Literature review provides a more detailed explanation, which argues that social enterprises are the initiatives that fulfil specific criteria. When J. Defourny presented the study conducted by the EMES network that aimed to identify the criteria distinguishing social enterprises, he defined two groups of criteria. The definition by EMES comprises 9 criteria distinguishing social enterprises, including economic, social and managerial ones. They are formulated in a relatively conservative way, which makes them more universal, but on the other hand limits their applicability and raises numerous interpretation-related concerns. The authors of the definition argue, however, that the criteria should not be regarded as necessary "conditions" that each organization has to fulfil to earn the label of the social enterprise, but they might rather serve as a description of "the ideal type" of such an enterprise (Defourny \& Nyssens, 2013, Defourny \& Nyssens, 2010). Despite various legal forms and areas of operation, social enterprises share a number of features:

- make a product or provides a service that involves business risk and it is verified in terms of the economic efficiency of this activity,

- are driven by social integration objectives on a scale of a given local community,

- give primacy to stakeholders' interests over shareholder relations,

- their management culture is based on partnership and participation,

- democratic control comes from stakeholders,

- the earned surplus and accumulated capital are not owned individually, but they are used to pursue a particular social mission (Mair \&d Marti 2006, Mason 2012).

Generally, the characteristic organisational forms that social enterprises adopt depend on the existing legal frameworks, on the political economy of welfare provision, and on both cultural and historical traditions of non-profit development in each country. As a consequence, the social enterprise sector nowadays may comprise both new typologies of organisations, as well as traditional third sector organisations (OECD, 2003). No matter the legal form, their principal purpose is not to generate commercial profit, but above all, to create workplaces for people at risk of social exclusion and professional marginalization (Sałustowicz, 2007) and engage in delivery of social services and work integration services for disadvantaged groups (such as people with disabilities) and communities (Wronka-Pośpiech \& Frączkiewicz-Wronka, 2014, Wronka-Pośpiech, 2018).

\section{Social enterprises in poland as a place of work for people with disabilities - polish perspective}

In Poland, despite few years of legislative effort, social enterprise is still an umbrella concept and neither official definition of social enterprise exists, nor a legal construct has been introduced into the system (Ciepielewska-Kowalik, Pieliński, Starnawska \& Szymańska, 2014). An attempt to 


\section{A. Frączkiewicz-Wronka, M. Wronka-Pośpiech, R. Porc}

provide a definition of a social enterprise has been recently made in the draft National Programme of Social Economy Development (KPRES, 2014), which defines social enterprise as an entity demonstrating the following characteristics:

- carrying out business activity with clear organisational boundaries and own financial reporting.

- the objective of business activity is either: or social and employment integration of people at the risk of social exclusion (operationalized as employing a minimum of 50 per cent of staff from among those at risk of social exclusion or at least 30 per cent of disabled); or o providing public benefit services while at the same time fulfilling pro-employment objectives.

- no distribution of profit or financial surplus among shareholders/partners; using profits or financial surplus to increase company capital, and in a certain share for: (a) social and employment integration, in case of enterprises with proemployment objectives; or (b) providing public benefit services for the local community where an enterprise operates.

- democratic governance or at least consultative role of employees and other stakeholders; and a salary cap for managers.

As highlighted in "A map of social enterprises and their eco-systems in Europe, Country Report: Poland" (EC, 2014), The National Programme (Krajowy Program Rozwoju Ekonomii Społecznej 2014) assumes the adoption of an Act on Social Enterprise which would introduce a social enterprise status enabling organisations to register as social enterprises on condition that they fulfil certain conditions. Nowadays in Poland a number of organisations with diverse institutional forms have many of the distinctive features of social enterprises and are often referred to as such in the public discourse. The broad spectrum of social enterprises consists of the following types of organisations (EC, 2014):

- Non-profit organisations, including foundations, established in order to implement socially or economically beneficial activities and self-governing non-profit voluntary associations that perform revenue-generating activities.

- Co-operatives for the disabled and blind (being a specific subgroup of labour cooperatives) and social cooperatives established to promote the social and professional reintegration of their members into the labour market.

- Vocational enterprises for the handicapped (ZAZ), objective of which is carrying out

- rehabilitation activities (rehabilitation of disabled, especially with severe disabilities) along with economic activities.

- Vocational therapy workshops (WTZ), which can be established by associations, foundations and other organisations and its primary objective is therapy and rehabilitation of disabled.

- Social integration centres (CIS) and social integration clubs (KIS), which organise educational programmes for people at risk of social exclusion and support individuals and their families in re-establishing and maintaining their ability to participate in the life of the local communities.

- Limited liability companies or corporations that pursue a public benefit mission (so-called non-profit companies).

However, basing on the nine guiding criteria by EMES, social cooperatives are closest to them when compared with other social enterprise models in Poland. What can be observed is a significant growth in their number as in 2009 there were 187 social cooperatives, in 2010 there were 276, in 2011 there were 402 social coops. This significant growth is a result of supporting social enterprises set up via public money, mainly European funds (Spółdzielnie...2019).

An analysis of key socio-economic challenges indicates the need for a new approach to the activation of specific categories of people who, due to the current labour market policy, were previously ignored. Institutional assistance to people with disabilities is a great opportunity for the development of the social economy sector, which, thanks to its flexibility and personalized approach, is an appropriate area to create jobs. In 2016, polish social economy sector comprised 90.9 thousand non-governmental (civic) organizations and 1.5 thousand active cooperatives, among which the majority of $60 \%$ they were social cooperatives. Social economy entities (in the segment of nongovernmental organizations) constituted 133.4 thousand in 2016 full-time jobs and 50,000 employed under civil law contracts, which represented $1.4 \%$ of average employment in the 
national economy. Which is characteristic for this sector are: feminisation of employment (nearly $2 / 3$ of employees), employment of people with disabilities twice as high as in the whole economy $(6.5 \%)$ and employment of people of retirement age $(6.4 \%)$ almost three times higher than in the national economy. This indicates the potential of the social economy sector as an organizer of jobs for people with difficulties in the labour market. In the cooperative segment of the social economy cooperatives for the disabled and blind as well as social cooperatives in 2017 employed over 33.5 thousand people on the basis of an employment relationship and approx. 2.4 thous. based on civil law contracts as the main form of employment. In total, in 2017, 11.9 thousand employees worked in cooperatives, among which the most numerous group were people with disabilities (10.1 thousand people) and the long-term unemployed (1.4 thousand people). This means that in the cooperative sector over $1 / 3$ of employees are people at risk on the labour market (in social cooperatives it is nearly $50 \%$ of people) (Spółdzielnie..2019) . Thus, the employment of these people in the cooperative sector is significantly higher than their employment in the economy and in non-governmental organizations. As for the economic condition of social enterprises, they are small entities of a local nature, with rather limited financial resources, carrying out tasks of low economic potential. Lack of resources results, among others due to the fact that support for enterprises is quite limited, which means that the expected growth requires additional support, among others through repayable instruments or other activities supporting social entrepreneurs. Of course, it should be remembered that social cooperatives, as well as other entities, especially those focused on employment and reintegration, often strive to balance their activities so as to ensure employment stability for employees, and not to maximize profits like other entrepreneurs. For this reason, these entities may encounter difficulties in accumulating capital necessary for investment and development, which means that it is in this area that the dedicated support should be provided.

\section{Two examples from polish ground}

Proof of the thesis on the need to create social cooperatives as important entity for the activation of people with disabilities in the labour market was provided by the analysis of the activities of two subjects - social coop Józefowskie Centrum Rehabilitacji Zawodowej i Społecznej (Vocational and Social Rehabilitation Centre) and social coop Fundusz Aktywizacji Niepełnosprawnych (Disability Activation Fund), both operating in the urban-rural municipality Józefów, Lublin Province. The Józefów commune is inhabited by approximately 7000 people (16\% at pre-working age, $64 \%$ at working age and $20 \%$ at post-working age), but due to the negative balance of births and migrations this number is decreasing. Both of presented social coops are relatively young institutions - The first one was established on 14 October 2009, the second one has been in operation since 30 August 2010. Employees of both cooperatives have a disability certificate. Analysis of employment data in both entities indicates a stable increase in the number of employees.

Table 2

The number of employees in ssocial coops in 2009-2018

\begin{tabular}{|c|c|c|}
\hline \multirow[b]{2}{*}{ Year } & \multicolumn{2}{|c|}{ Number of persons employed } \\
\hline & $\begin{array}{c}\text { Social coop } \\
\text { Vocational and } \\
\text { Social } \\
\text { Rehabilitation } \\
\text { Centre of Józefów }\end{array}$ & $\begin{array}{c}\text { Social coop Józefów } \\
\text { Disability Activation } \\
\text { Fund }\end{array}$ \\
\hline 2009 & 6 & - \\
\hline 2010 & 15 & 12 \\
\hline 2011 & 16 & 14 \\
\hline 2012 & 16 & 18 \\
\hline 2013 & 28 & 18 \\
\hline 2014 & 37 & 22 \\
\hline 2015 & 42 & 21 \\
\hline 2016 & 46 & 22 \\
\hline 2017 & 44 & 22 \\
\hline 2018 & 44 & 22 \\
\hline
\end{tabular}

Source: own elaboration

The Social Cooperative Józefowskie Centrum Rehabilitacji Zawodowej i Społecznej (Józefów Social and Vocational Rehabilitation Centre) used a grant from the District Labour Office and European funds to start its activity. Currently, it benefits from a grant from the State Fund for Rehabilitation of Persons with Disabilities, funds from the commune 


\section{A. Frączkiewicz-Wronka, M. Wronka-Pośpiech, R. Porc}

budget, subsidies from the Labour Fund and European funds. The cooperative's activity concerns: performing services for the population in the field of cleaning, greenery care, housework, servicing the kindergarten department, running a rural common room, running school canteens in primary schools and kindergartens and performing conservation services for primary schools and kindergartens. The scope of activity is adjusted to the possibility of providing work by disabled persons employed by the entity. Financial support for the establishment of the second organization, the social coop Disability Activation Fund in Józefów was obtained from European funds and subsidies from the State Fund for Rehabilitation of the Disabled. The main areas of activity of the Disability Activation Fund are: running a milk bar; cleaning the City Public Library; running a temporary animal shelter; maintaining order in the city; running protected flats; running a website and the Public Information Bulletin of the City Hall in Józefów. The current functioning of the cooperative is mostly supported by the State Fund for the Rehabilitation of the Disabled, in addition, it also receives grants from the Labour Fund and funds from municipal local government units.

Cooperatives are not profit oriented and aim at current revenues to cover current liabilities. The character of the activity is targeted at activating disabled people, cooperation with the local environment, minimizing unemployment in the commune among the group of excluded people. The financial condition of both entities was described by the respondents as good.

Table 3

Profits from business activity

\begin{tabular}{|c|c|c|}
\hline \multirow[b]{2}{*}{ Year } & \multicolumn{2}{|c|}{ Profit } \\
\hline & $\begin{array}{c}\text { Social coop } \\
\text { Vocational and } \\
\text { Social } \\
\text { Rehabilitation } \\
\text { Centre of Józefów }\end{array}$ & $\begin{array}{c}\text { Social coop } \\
\text { Józefów Disability } \\
\text { Activation Fund }\end{array}$ \\
\hline 2012 & 8926,00 & 17893,06 \\
\hline 2013 & 20706,43 & $-32291,19$ \\
\hline 2014 & 28862,16 & 40032,64 \\
\hline 2015 & 8183,89 & $-9234,64$ \\
\hline 2016 & 24385,57 & 4118,67 \\
\hline 2017 & 45430,25 & b. d. \\
\hline
\end{tabular}

Source: own elaboration
It should be recalled that the function of social enterprise is not only to produce specific goods and services, but above all to mobilise social capital, generate innovation and expand the market by including those who are hitherto excluded. A social enterprise is a specific part of a market economy, as it places its mission and goals outside the market. As already mentioned, the number of social cooperatives, despite the fact that they are a relatively new institution on the market, is growing rapidly, mainly as a result of European funds. Social cooperatives are mostly active in accommodation and catering services, health care and social assistance. A large part of them also operate in the field of administrative services and industrial processing. The largest part $(45 \%)$ of social cooperatives employs between 1 and 5 employees on the basis of an employment relationship, only $12 \%$ of cooperatives employ more than 10 employees. More than one fourth of cooperatives employ employees only on the basis of civil law contracts. The cooperative often employs people on short-term contracts, which may be associated with seasonal work. Social cooperatives can benefit from many forms of support from public funds. National forms of support include the Labour Fund and State Fund for Rehabilitation of the Disabled (PFRON), support can also be obtained from local government institutions, foundations, private investors, they can also apply for reimbursement of social security contributions, or use the European Social Fund.

\section{Potential risks to the functioning of social enterprises - municipality and social entrepreneur perspective}

No matter how promising is the perspective of establishing social enterprises in order to alleviate social problems and enhance process of professional activation of persons with disabilities, it is necessary that decision-makers at the municipality level bear in mind everyday problems in the functioning of social cooperatives and take them into consideration prior to action.

In order to study risks in the activity of social enterprises modified questionnaire proposed in the Canadian social enterprise guide was used (Enterprising Non-Profits Program, 2005). Adopted measure consist 26 statements related to potential risks. The questionnaire was used to collect data in 


\section{Social enterprises as place of work for people with disabilities - evidence from Poland}

the form of subjective opinion of respondents. Prior to this research, thorough examination of secondary data sources (foreign and domestic literature, published studies) was conducted. On this basis, the research tool was created making possible to collect the information about respondents' perception of potential risk factors. Target group in this research were representatives of top management (social entrepreneurs, managers managing social enterprises). Managers of social enterprises (social entrepreneurs) received the questionnaire directly, as variables used in the study require information to be provided by people who have a good knowledge of the functioning and development of the whole organisation. The respondents assessed a series of 26 statements, declaring the degree to which the statements accurately describe perilous situations. Responses range along a seven-point scale (1, "strongly disagree," to 7, "strongly agree"). The research was conducted in social enterprises operating in the formula of social cooperative based throughout Poland. The sample was selected randomly and comprised 160 social cooperatives (which equals $19 \%$ of the total population), thus our sample formally meets the criteria of representativeness. Research took place in the period from 1 May 2015 to 30 June 2015.

The research indicates that ten out of twenty six surveyed risk factors can be considered as critical. The study helped to identify a hierarchy of risks in the activity of social enterprises. The analysis of the overall evaluation of the distinct areas (calculated as the mean of each respondent's rating of the items in the areas) demonstrated that, according to the respondents, the following risks are the most crucial for the organisation: (1) the lack of employee involvement, (2) damage to the brand and reputation, (3) a decrease in the income (revenue), (4) a failure to comply with, or a violation of, terms and conditions of the contract, (5) the responsibility we bear for the quality of goods/services, (6) a deterioration of market conditions, (7) intentional or unintentional actions to the detriment of customers, (8) a failure to comply with or a breach of the contract by the operators and organizations we work with (partners), (9) a theft of cash earned by the organization (10) the loss of funding (WronkaPośpiech, Frączkiewicz-Wronka \& Laska 2017).
It is especially important due to the dynamic growth in the number of social cooperatives in the recent two years, being a result of supporting the social enterprise set-up via public money (European funds in particular). These funds have proven to be a great incentive for individuals that are socially or economically excluded. However in the next programming cycle $2020+$, they should be spent more wisely, for example on additional coaching or mentoring after the start-up phase, in order to prevent social coops from closing down after the end of financing period.

In sum, social services underlie certain quality and standard of living. Logic, that stands behind social services, guaranteed by amended European Social Card and Universal Declaration of Human Rights, secure the society in respecting their rights to social justice, bringing social cohesion. Public authorities have a general responsibility for efficient operation of social services. Not only additional funds maintain a high level of quality but also provision of knowledge and expertise. Hence the need for special attention to potential risks, which may destructively affect continuous growth of social sector. In fact, their precise identification may assist in the preparation of such a management tool, which may increase the effectiveness of social enterprises in fulfilling their organisational objectives. Social services in all EU countries are provided by a wide range of organizations from the social sector. The largest proportions of them are those with objectives to help the society, increase the welfare, but gain no profit from operations (associations, cooperatives, foundations). Derived from various initiatives (public, charitable, philanthropic, religious, private, etc.) fulfil an important role. The more so, because the nature of socio-economy-behavioral characteristics of people forming them, hamper smooth functioning on the open market.

Summing up the results of presented research results, social coops in Poland most often face with lack of understanding and interest from local authorities, which could not only be a source of contracts (for example by using social clauses) but also could help them through counselling and support. Social cooperatives also have difficulties with gaining new orders and contracts on the commercial and public market - especially as the 


\section{A. Frączkiewicz-Wronka, M. Wronka-Pośpiech, R. Porc}

latter are a subject of complicated public tendering procedures.

\section{Conclusions}

In order to cope with the professional activation of people with disabilities the pattern of change should start from the immediate environment and living space of disabled. Increasing the number of employment opportunities (e.g. in the form of homework), create and ease the options for self-employment (e.g. social cooperatives). The substantial expansion of educational opportunity should also take place. The longer time-perspective, focuses on developing macro solutions designed to ensure that jobs are available for everyone who wants to work. These, indeed optimistic, long-term objectives are realistic and achievable, but with significant amount of resources. Nowadays in many European countries social enterprises turned out to be a cost-effective and socially acceptable solution aimed at supporting a worthy life of people with disabilities. Gathered data shows that if the gap between the participation rate and unemployment rate for people with disability could be reduced, the cumulative impact on economy would be significant. Improving employment opportunities for people with any kind of disability is a critical element for enhancing the quality of life for handicapped, their families and carers, which is why introduction of social enterprises is so important. The new programming period for the objectives financed from European Union aid funds 2020+ through increasing the resources clearly demonstrates the growing role of the social economy and social enterprises in the implementation of public policies aimed at reintegration of the socially marginalized groups, the disabled, on the labour market.

\section{References}

1. Badania Aktywności Ekonomicznej Ludności wyrównane sezonowo w latach 2010-2018 (2018). Warszawa: GUS.

2. Ciepielewska-Kowalik, A., Pieliński, B., Starnawska, M., Szymańska, A. (2015). Looking for Social Enterprise Models in Poland: Institutional and Historical Context. ICSEM Working Papers, No. 2015-11, The International Comparative Social Enterprise Models (ICSEM) Project, ICSEM Working Papers, No. 2015-11. Liege.
3. Dacin, P.A., Dacin, M.T., Matear, M., (2010). Social entrepreneurship: why don't need a new theory and how we move forward from here. Academy of Management Perspectives, 24(3), 3757. https://doi.org/10.5465/amp.24.3.37

4. Dart, R. (2004). Legitimacy of Social Enterprise. Nonprofit Management and Leadership, 14(4), 411424. https://doi.org/10.1002/nml.43

5. Defourny, J., \& Nyssens M. (2013). Social Coops: When Social Enterprises meet the Cooperative tradition. Journal of Entrepreneurial and Organizational Diversity, 2(2), 11-33. http://dx.doi.org/10.5947/jeod.2013.008

6. Defourny, J., \& Nyssens, M. (2010). Conceptions of Social Enterprise and Social Entrepreneurship in Europe and the United States: Convergences and Divergences. Journal of Social Entrepreneurship, 1(1), 32-53. $\quad$ http://dx.doi.org/10.1080/ 19420670903442053

7. European Commission. (2014). A map of social enterprises and their eco-systems in Europe. Country Reports: Poland. Brussels: European Commission Directorate General for Employment, Social Affairs and Inclusion.

8. European Disability Strategy 2010-2020: A Renewed Commitment to a Barrier-Free Europe, COM(2010) 636 final, SEC(2010) 1324 final; Brussels, 15.11.2010 SEC(2010) 1323 final. Retrieved from: https://eur-lex.europa.eu/ LexUriServ/LexUriServ.do?uri=SEC:2010:1324:F IN:en:PDF

9. Haugh, H. (2006). Social enterprise: Beyond economic outcomes and individual returns. In J. Mair, J. Robinson, K. Hockerts, (Eds.), Social entrepreneurship, 180-206. Basingstoke, UK: Palgrave Macmillan. Retrieved from: http://citeseerx. ist.psu.edu/viewdoc/download?doi=10.1.1.458.668 $3 \&$ rep $=$ rep $1 \&$ type $=p d f$

10. Hausner, J., Laurisz, N., \& Mazur, S. (2007). Przedsiębiorstwo społeczne - konceptualizacja. In J. Hausner (Ed.), Zarzadzanie podmiotami ekonomii społecznej, 9-22. Kraków: Małopolska Szkoła Administracji Publicznej. https://doi: 10.1108/03068290610660643

11. Krajowy Program Rozwoju Ekonomii Społecznej (2014), Uchwała nr 164 Rady Ministrów z dnia 12 sierpnia 2014 r. w sprawie przyjęcia programu pod nazwa "Krajowy Program Rozwoju Ekonomii Społecznej do 2023 roku. Ekonomia Solidarności Spolecznej", Monitor Polski 2014 poz. 811, Retrieved from: http://prawo.sejm.gov.pl/isap.nsf/ DocDetails.xsp?id=WMP20140000811

12. Leś, E. (2007). Rola trzeciego sektora $w$ polityce spotecznej. In G. Firlit-Fesnak, M. Szylko-Skoczny 
Social enterprises as place of work for people with disabilities - evidence from Poland

(Eds.), Polityka społeczna, 361-372. Warszawa: $P W N$.

13. Mair, J., \& Martí, I. (2009). Social entrepreneurship in and around institutional voids. A case study from Bangladesh. Journal of Business Venturing, 24(5), 419-435. https://doi.org/10.1016/ j.jbusvent.2008.04.006

14. Mason, C. (2012). Up for grabs: A critical discourse analysis of social entrepreneurship discourse in the United Kingdom. Social Enterprise Journal, 8(2), 123-140. 17508611211252846

https://doi.org/10.1108/

15. Mokrzycka, A., (2012). European Strategies Towards Rights of Disabled Persons - the meaning of The Disability action plan and European disability Strategy 2010-2020. Polityka Społeczna, special issue, 61-70, Warszawa

16. OECD (2003). The Non-profit Sector in a Changing Economy, Paris. Retrieved from: https://www. oecd.org/ cfelleed/thenon-profitsectorinachangingeconomy.htm Satustowicz P. (2007). Pojęcie, koncepcje i funkcje ekonomii społecznej. In J. Starega-Piasek (Ed.) Ekonomia społeczna. Perspektywa rynku pracy $i$ pomocy spolecznej, Instytut Rozwoju Stużb Społecznych, 21-46. Warszawa
18. Spółdzielnie jako podmioty ekonomii społecznej $w$ 2017 r. (2019). Warszawa: GUS.

19. Thompson, J., \& Doherty, B. (2006). The diverse world of social enterprise: A collection of social enterprise stories. International Journal of Social Economics, 33(5/6), 399-410.

20. Wronka-Pośpiech M., Fraczkiewicz-Wronka A., Laska K. (2017). Risk perception in the activity of social enterprises. In K. Raczkowski (Ed.), Risk Management in the Public Administration, 189225, London, New York: Palgrave Mcmillan. DOI 10.1007/978-3-319-30877-7

21. Wronka-Pośpiech, M. (2018). Rola liderów w sukcesie przedsiębiorstw społecznych. Katowice: Wydawnictwo UE Katowice.

22. Wronka-Pośpiech, M., \& Fraczkiewicz-Wronka, A. (2014). The use of ICT for achieving the objectives of the business model - social enterprise perspective. Polish Journal of Management, 2, 33-42.

23. Zratek, M., \& Borski, M., (2018). Wspomaganie niezależnego życia $i$ właczanie $w$ spoteczeństwo osób z niepetnosprawnościami w praktyce - kilka uwag na tle wdrażania Konwencji o prawach osób niepetnosprawnych. Themis Polska Nova, 1(13), 81106. Retrieved from: https://czasopisma.marszalek. com.pl/images/pliki/tpn/Themis2018_13.pdf 